Volume 13

Number 12013

Article 5

December 2013

\title{
Morality of Contraceptives Based on When Personhood Begins
}

Joella R. Gerber

Cedarville University, joellagerber@cedarville.edu

DigitalCommons@Cedarville provides a publication platform for fully open access journals, which means that all articles are available on the Internet to all users immediately upon publication. However, the opinions and sentiments expressed by the authors of articles published in our journals do not necessarily indicate the endorsement or reflect the views of DigitalCommons@Cedarville, the Centennial Library, or Cedarville University and its employees. The authors are solely responsible for the content of their work. Please address questions to dc@cedarville.edu.

\section{Recommended Citation}

Gerber, Joella R. (2013) "Morality of Contraceptives Based on When Personhood Begins," CedarEthics: A Journal of Critical Thinking in Bioethics: Vol. 13 : No. 1 , Article 5.

DOI: 10.15385/jce.2013.13.1.5

Available at: http://digitalcommons.cedarville.edu/cedarethics/vol13/iss1/5 


\title{
Morality of Contraceptives Based on When Personhood Begins
}

Browse the contents of this issue of CedarEthics: A Journal of Critical Thinking in Bioethics.

\begin{abstract}
The use of contraceptives has been controversial in recent days, especially concerning the government mandate for insurance and health care companies to financially cover contraceptives for their policy holders. The term 'contraceptive' includes anything that deliberately prevents conception or impregnation, including condoms, birth control pills, intrauterine methods, and barrier methods (Merriam-Webster, 2013). The morality of contraception largely hinges on the belief of when personhood begins.
\end{abstract}

\section{Keywords}

Contraception, personhood, morality, ethics

\section{Creative Commons License}

\section{(c) $(1) \Theta \Theta$}

This work is licensed under a Creative Commons Attribution-Noncommercial-No Derivative Works 3.0 License.

Follow this and additional works at: http:// digitalcommons.cedarville.edu/cedarethics

Part of the Bioethics and Medical Ethics Commons 


\title{
Morality of Contraceptives Based on When Personhood Begins
}

\author{
Joella Gerber \\ Cedarville University
}

\begin{abstract}
1 The use of contraceptives has been controversial in recent days, especially concerning the government mandate for insurance and health care companies to financially cover contraceptives for their policy holders. The term 'contraceptive' includes anything that deliberately prevents conception or impregnation, including condoms, birth control pills, intrauterine methods, and barrier methods (Miriam-Webster, 2013). The morality of contraception largely hinges on the belief of when personhood begins.
\end{abstract}

Throughout history, religious, scientific, and philosophical ideas surrounding the beginning of personhood have created dissention about the moment when a human being becomes a person. This debate has been especially important among Christians, and opposing views have further separated Roman Catholics and Protestant Evangelicals.

One view of personhood, largely endorsed by the Roman Catholic magisterium, is that personhood begins at the moment when God thinks of the being. Supporters of this view use Psalm 139 and Ephesians 1 as a basis. For example, Psalm 139:13-16 says that God knew David when he was "being made in secret" and when he was an "unformed substance" (ESV). This might suggest that God knows people before they are born, or even before they are conceived.

It is worth noting the cultural background from which the biblical authors were writing. They did not understand science in the way science is currently viewed in our day. While the "in God's mind" view may be correct from a Christian perspective, it is difficult to prove scientifically. Law and science would not accept this as a feasible starting point for personhood. And as a practical matter it is difficult to define when exactly God first thought of each individual person.

Though there are many arguments against such a view, the Catholic Church defends the "God's mind" idea strongly in practice, which informs its view on contraception. While the magisterium does claim that conception is the beginning of personhood, in practice it acts as if a human being is a person before conception. In this paper, I will demonstrate the merits of this view and provide a critique. In short, Catholics believe that God has a will for each person before conception. If personhood begins with God's thought of a person, using contraception therefore would seem to go against God's will. On this view, it interferes with God's plan for that potential human being.

Many believe that personhood begins at fertilization, when the genes from two parent cells combine to create a unique genome (Gilbert, Tyler, \& Zackin, 2005). From this point forward, the organism has all it needs to become a fully functional person, and therefore the blastocyst should be considered a person. Many Protestants support this conception view of the origin of personhood, which strongly informs the Protestant view of contraception. If personhood begins 
at fertilization, that has implications for the use of contraceptives. On this view, because personhood does not occur prior to fertilization, the prevention of fertilization is moral. Personhood is not stopped; rather it is prevented from beginning.

One of the most prominent voices against contraception comes from the Catholic encyclical Humanae Vitae, a theological document given by Pope Paul VI in 1968. The Humanae Vitae focuses on the principles that define marriage and the responsible use of those principles (Massa, 2010). These include: duties toward God, towards marriage, toward the people themselves, and toward society. The main duty owed God is to respect his purpose for marriage and the act of sex. According to the Humanae Vitae, sex is a sacred marital act, intended as an act of procreation. To use sex for any other means than procreation is to ignore God's will for marriage.

This idea applies to the use of hormonal contraception as well (Bromberg, 2007). When a couple uses contraception, according to the Catholic Church, they are interfering with God's will for marriage, as well as His plan for a person to be conceived and born. In fact, following the publication of Humanae Vitae, Catholic French bishops asserted that contraception can never be good (Parkinson, 2013). Contraception works in direct defiance of the actualization of the person that God had in mind. Pope Paul VI had suggested that couples who did not wish to become pregnant should refrain from sex during the infertile time of the month. This birth control method is often called the "calendar" or "rhythm" method. This would not be considered going against God's will for sex because it is a natural way of preventing pregnancy.

Because of the relation of body and soul, it is also immoral to use contraception to prevent the coming together of these two aspects of personhood (Murphy, 2011). God has planned for the body and soul of a being to come together to form a person. To purposefully deny that union is a sin.

Murphy also argues that it is a Biblical mandate to procreate. Using contraceptives in order to prevent pregnancy fails to fulfill the creation mandate given in Genesis 1 to "be fruitful and multiply and fill the earth." He also argues that by denying personhood to a being, the Body of Christ is robbed. The baby prevented by the use of contraceptives was a key part of the Body of Christ that will never come to fulfillment.

The Catholic Church also argues against contraception using natural law. John Ryan, a Catholic theologian of the early twentieth century, spoke out against contraception (Mulloy, 2013). He chose to argue from natural law because he felt that society would not accept the authority of the Church, but might accept the use of reason and natural law. On his view, the natural purpose of sex is to procreate. When having sex for any other reason, or purposely interfering with the process of procreation, is a perversion of a natural function (Mistal \& Dannefer, 2010). Because they go against what is naturally normal, it is immoral to use contraceptives. He also argued that bad consequences would come from the use of contraception, including the degrading of the marital relationship, a cultural decline, and a lower birthrate, which would reduce population. None of these is beneficial to society as a whole.

One specific way contraceptives negatively affect a marital relationship, according to Bedford 
(2012), is through the demeaning of spouses due to the fulfillment solely of sexual desires. When sex is justified because "we are not going to get pregnant," it dehumanizes one's spouse. It ignores the needs of the other spouse in order to fulfill one's own desires. It lowers the value of the other person by putting one's desires above that of the spouse. This is outside God's will for the way that married couples should treat one another.

While other denominations may not have as strong of an opinion on contraception, they do have views on how the will of God plays into contraceptives. The Eastern Orthodox Church does not have any official opinion on the use of contraceptives. However Zaphiris (1974) believes that refusing to give life to any being is morally wrong. This applies to potential persons, who are given the title of personhood by the thought of God. This is similar to the view of Catholics on when personhood begins.

For most of history, the majority of Christianity thought that it was a sin to intentionally interfere with conception as a consequence of sexual intercourse. However, ninety percent of Americans today, including Roman Catholics and Evangelical Christians, do not think of contraceptives as immoral (Kaveny, 2006). Schwenkler (2012) argues that in order to show contraceptive use immoral, there must be evidence that contraceptive use is "wrong intrinsically, or it is wrong on certain occasions because of an illicit end" (p. 674). He feels, however, that contraception is not immoral, because taking a pill or using a condom by itself is not wrong. It is also not immoral to plan to not to have children. Therefore, using contraception is not immoral, because it is neither intrinsically wrong, nor done for an evil purpose. In fact, many people find the use of contraceptives praiseworthy. For example, a woman who protects herself and her future children by not having more would be considered morally praiseworthy.

Bedford (2012) points out that the wording in Humanae Vitae is too ambiguous to be authoritative for the Catholic Church. He points out that the term "natural" is used often in the document, but is not easily defined. Though natural things are often contrasted with artificial, natural family planning could be construed as a form of contraception that the Catholic Church does not support. He also argues that the Church needs to convey its message by showing the harm contraceptives can bring to relationships, and the harm of denying God's will for the unborn person. When Catholics, especially those in America, approach this topic, they see it as a rule without reasons. Though Bedford agrees with the proscription of contraceptives, he encourages the Church to reexamine the reasoning behind its position and to change how it advertises its mandates to the public. He claims that the Church would do well to emphasize grace.

While the Eastern Orthodox Church believes that refusing to give life to a being is immoral, they also believe that contraception may be used in certain cases in a morally acceptable way (Zaphiris, 1974). One such case is in that of a married couple that already has multiple children. If the couple does not feel it would be wise to extend their family, for social, economic, emotional, or physical reasons, contraception is not an immoral decision. While Zaphiris does not think contraception is the first step that such a couple should take, he approves it as moral. It does not deny a being personhood, it rather prevents personhood from beginning. 
In my opinion, it is not immoral to use contraceptives to prevent pregnancy. I believe that personhood begins at conception, rather than when the thought of a person enters the mind of God. This stems from the philosophical idea of substance. According to this view, a substance retains its identity through change (Moreland \& Rae, 2002). There is also unity and wholeness in the parts of a substance, including the unity of the physical body and the soul. I believe this process and unity start at conception as the genes of two parents come together to form one human embryo. Because personhood begins at conception, the use of contraceptives is moral. It does not stop the physical beginning of a person, but rather prevents the beginning of personhood.

Conception as the beginning of personhood can also be supported scientifically. Scientists do not disagree that a human being will form after conception as long as no other extraneous problems interfere with development (Gilbert, Tyler, \& Zackin, 2005). After the blastocyst implants in the uterine wall, it takes less than two weeks for cells to start differentiating. Because the physical body continues to develop into a functioning human being, and based on the identity property of substance, I personhood must being at conception, as supported scientifically and philosophically.

I strongly agree with Schwenkler's (2012) argument for the morality of contraceptives, as mentioned above. Because there is nothing intrinsically wrong with contraceptives, and because the end of not having a child is also morally acceptable, the act of using a contraceptive is moral. This compliments my belief that it is not immoral to prevent a pregnancy by any means, whether through contraceptives or through natural birth control.

I also do not believe that the mandate in Genesis to fill the earth is a direct message to all people to have children. Genesis 1:28, God commands people to "be fruitful and multiply and fill the earth." In this passage, God is talking specifically to Adam and Eve, and furthermore, to humanity as a whole. He is not commanding each person to have children in order to fill the earth.

I, along with many Catholic theologians, do not support the mandate against contraception given in Humanae Vitae by Pope Paul VI (Parkinson, 2013). While I cannot know the motives for declaring the immorality of contraceptives, there is compelling evidence that his declaration was based on more than conscience, biblical thinking, and the Holy Spirit's guidance.

The Pope's encyclical seems grounded more on than his belief about God's view of persons and when life begins. Turina (2013) argues that the Pope gave his encyclical based on the shrinking number of Catholics in the world. The Catholic Church has been a world power for centuries, largely due to its sheer number of followers. Around the time of the mandate, the number of members of the Church was plummeting, largely due to lower birth rates. A loss of membership in the Church would have a great impact on the Church's authority worldwide. Many speculate that this may a reason why the Catholic Church denies the morality of contraceptive use. The ban on contraceptives might lead to a greater number of children raised in the Catholic Church, allowing the Church to keep its worldwide power. 
It also seems curious that the Pope claims that a decline in sexual morality and a rise in the exploitation of women would follow from contraceptive use, or even that governments would impose contraceptive agents on their citizens (Bromberg, 2007). Contraception is frequently discussed in the Church, whereas other similar topics, such as masturbation and pornography, have been left in the dust, largely unmentioned (Turina, 2013). While the Church's concern about sexual morality in regard to culture is important, it does not seem to be the reason for their push for the immorality of contraception.

Many Catholic laypersons, as well as theologians, also struggle with the doctrine of conscience as it relates to the use of contraceptives. The doctrine of conscience is the "practical judgment or dictate of reason by which one judges...good or...evil" (Parkinson, 2013, p. 300). While the direction given by Popes is authoritative, conscience also plays a large role in the morality of certain actions. If a couple feels that they ought to use contraceptive measures, that it is moral for them, regardless of the Pope's opinion or statement. According to the doctrine of conscience, they are allowed to use contraception. This conflicts directly with Humanae Vitae.

This makes it difficult for the Church to take a stance on a position, no matter its belief on personhood. I struggle to agree with a mandate when many leaders in the Catholic Church, including bishops and cardinals, agree that there are exceptions to such a mandate (Nagle, 2013). If the Church considers the use of contraceptives moral or immoral in one case, I feel that such a mandate should apply to every person.

In my opinion, the Catholic Church is naïve in its expectation that members will not use contraceptives. Even in Catholic countries, government policies have not prevented the use of contraceptive agents. This is especially true in Poland. Following the fall of the Soviet Union, Catholic leaders took over the Polish government (Mishtal \& Dannefer, 2010). However, despite their efforts, the use of contraception has not decreased in Poland. In fact, seventy-nine percent of women reported that religious influence did not influence on their reproductive decisions. Many women surveyed claimed it was more of a sin to not be able to care for their family properly than to use birth control methods. Women also claimed that the Church is unloving and cruel, because by denying the use of birth control, more babies are left to die because they could not be supported by their mothers. If the Church wishes to be more effective in its ban on contraception, it need to change the way that message is presented.

The way in which people view the beginning of personhood has a large effect on their view of contraception. If personhood begins before conception, it is logical that contraception would be immoral, because it is does not allow a person to become a living being: it robs a person of life. However, if personhood begins at conception or after, contraception simply prevents a human from forming. No life is taken or robbed; it is simply not permitted to begin. If so, then use of contraceptives is moral and within the will of God.

\section{References}

Bedford, E. (2012). Reframing the contraception debate. Ethics \& Medics, 37(9), 1-4.

Bromberg, H. (2007). Humanae vitae. Masterplots II: Christian Literature, 1-2. 
Contraception. (2013) In Merriam-Webster's online dictionary. Retrieved from http://www.merriam-webster.com/dictionary/contraception

Gilbert, S. F., Tyler, A. L., \& Zackin, E. J. (2005). Bioethics and the new embryology: Springboards for debate. Sunderland, MA: Sinauer Associates.

Kaveny, C. (2006). Contraception, again. Commonweal, 133(22), 6.

Massa, M. S. (2010). Humanae Vitae in the United States. Oxford University Press. doi:10.1093/acprof:oso/9780199734122.003.0003

Mishtal, J., \& Dannefer, R. (2010). Reconciling religious identity and reproductive practices: The Church and contraception in Poland. European Journal Of Contraception \& Reproductive Health Care, 15(4), 232-242. doi:10.3109/13625187.2010.498595

Moreland, J. P., \& Rae, S. (2002). Body and soul: Human nature \& the crisis in ethics. Downers Grove, Ill.: InterVarsity Press.

Mulloy, C. (2013). John A. Ryan and the issue of family limitation. Catholic Social Science Review, 18, 91-104.

Murphy, W. (2011). Revisiting contraception: An integrated approach in light of the renewal of Thomistic virtue ethics. Theological Studies, 72(4), 812-847. doi: $10.1177 / 004056391107200406$

Nagle, C. M. (2013). Giving due emphasis to the human person in Catholic moral teaching. Australasian Catholic Record, 90(1), 47-59.

Parkinson, J. (2013). Humanae vitae II: Conscience, contraception and holy communion. Australasian Catholic Record, 90(3), 297-310.

Paul VI. Vatican II. Humanae vitae. 25 July 1968. 10 Dec. 2013. Retrieved from http://www.vatican.va/holy father/paul vi/encyclicals/documents/hf pvi enc 25071968 humanae-vitae en.html

Schwenkler, J. (2012). Michael Dummett on the morality of contraception. Heythrop Journal, 53(5), 763-767. doi:10.1111/j.1468-2265.2010.00634.x

Turina, I. (2013). Vatican biopolitics. Social Compass, 60(1), 134-151. doi: $10.1177 / 0037768612471776$

Zaphiris, C. (1974). Morality of contraception: An Eastern Orthodox opinion. Journal Of Ecumenical Studies, 11(4), 677-690. 